Short communication

\title{
INVOLVEMENT OF SEROTONERGIC, NORADRENERGIC AND GABAERGIC SYSTEMS IN THE ANTINOCICEPTIVE EFFECT OF A KETAMINE-MAGNESIUM SULFATE COMBINATION IN ACUTE PAIN
}

\author{
SAVIĆ VUJOVIĆ Katarina ${ }^{1 *}$, VUČKOVIĆ Sonja ${ }^{1}$, STOJANOVIĆ Radan ${ }^{1}$, \\ DIVAC Nevena ${ }^{1}$, MEDIĆ Branislava ${ }^{1}$, SREBRO Dragana ${ }^{1}$, KADIJA Marko ${ }^{2}$, \\ PROSTRAN Milica ${ }^{1}$ \\ ${ }^{1}$ Department of Pharmacology, Clinical Pharmacology and Toxicology, Faculty of Medicine, University \\ of Belgrade, Belgrade, Serbia; \\ ${ }^{2}$ Clinical Centre of Serbia, Institute for Orthopaedic Surgery and Traumatology, Belgrade, Serbia
}

(Received 16 June, Accepted 28 December 2017)

Ketamine and magnesium can interact in additive, supra-additive and antagonistic manners in analgesia or anesthesia. Ketamine is a non-competitive NMDA receptor antagonist. Magnesium is an endogenous non-competitive NMDA antagonist that causes anion channel blockade in a dose-dependent manner. It has been established that ketamine and magnesium interact synergistically in the tail-immersion test in rats.

To determine the role of serotonergic, GABAergic and noradrenergic systems in analgesia induced by the ketamine-magnesium sulfate combination.

Experiments were performed on male Wistar albino rats (200-250 g). Antinociception was evaluated by the tail-immersion test.

Methysergide ( 0.5 and $1 \mathrm{mg} / \mathrm{kg}, \mathrm{sc}$ ) administered alone did not affect nociception in rats. Methysergide $(0.5$ and $1 \mathrm{mg} / \mathrm{kg}$, sc) antagonized the antinociceptive effect of the ketamine $(5 \mathrm{mg} / \mathrm{kg})$-magnesium sulfate $(5 \mathrm{mg} / \mathrm{kg})$ combination. Bicuculline $(0.5$ and $1 \mathrm{mg} / \mathrm{kg}$, sc) given alone did not change the threshold to thermal stimuli in rats. Bicuculline ( 0.5 and $1 \mathrm{mg} / \mathrm{kg}$, sc) antagonized the antinociceptive effect of the ketamine $(5 \mathrm{mg} / \mathrm{kg})$-magnesium sulfate $(5 \mathrm{mg} / \mathrm{kg})$ combination. Yohimbine $(0.5,1$ and $3 \mathrm{mg} / \mathrm{kg}$, sc) applied alone did not change nociception. Yohimbine at a dose of $0.5 \mathrm{mg} / \mathrm{kg}$ did not influence the effect of ketamine $(5 \mathrm{mg} / \mathrm{kg})$-magnesium sulfate $(5 \mathrm{mg} / \mathrm{kg})$, while yohimbine at doses of 1 and $3 \mathrm{mg} / \mathrm{kg}$ antagonized the antinociceptive effect of this combination.

Serotonergic, noradrenergic and GABAergic systems participate, at least in part, in the antinociceptive effect of the ketamine-magnesium sulfate combination in acute pain in rats.

Key words: analgesia, bicuculline, ketamine, magnesium, methysergide, yohimbine

\footnotetext{
*Corresponding author: e-mail: katarinasavicvujovic@gmail.com
} 


\section{INTRODUCTION}

Ionotropic receptors have an important role in the pathogenesis of pain. N-methylD-aspartate (NMDA) receptors are present in the dorsal root ganglia of the spinal cord and in certain pre- and postsynaptic parts of the spinal cord and brain. These receptors in the ascendant and descendent pathways modulate the transmission of nociceptive stimuli from the periphery [1]. The nociceptive impulses which are transmitted in the spinal cord by unmyelinated $C$ fibers and myelinated A $\delta$ fibers, lead to glutamate release in the spinal cord and to the sensation of pain. Pain modulation refers to the process by which the body alters a pain signal. Descending pathways project to the dorsal horn and inhibit pain transmission. Descending inhibition of pain is mostly accomplished by enkephalins, 5-hydroxy tryptamine (5-HT, serotonin) and noradrenaline (NA). Serotonin receptors can be pro- $\left(5-\mathrm{HT}_{3}\right)$ and antinociceptive $\left(5-\mathrm{HT}_{1}\right)[2]$, whereas all central noradrenergic receptors are antinociceptive [3].

The balance between the activity of inhibitory and excitatory amino acids, gammaaminobutyric acid (GABA) and glutamate determines the level of pain transmission [4]. The role of GABA transmission in the spinal cord can vary in different pain states. Opioids enhance the descending inhibitory pain pathway by suppressing the inhibitory influence of GABA on neurons that form this antinociceptive pathway [5].

Ketamine is an NMDA receptor antagonist with a clinical application. It is a dissociative anesthetic with an analgesic effect at subanesthetic doses [6]. The mechanisms of ketamine anti-nociceptive actions include activation of descending inhibitory monoaminergic pain pathways and antagonism of NMDA receptors [7]. Ketamine has little risk of cardiorespiratory depression and is an excellent drug for the treatment of pain in trauma [8]. The adverse effects of ketamine are produced at therapeutic doses and include sedation, motor coordination, confusion, hallucinations.

Magnesium is physiologically a non-competitive N-methyl-D-aspartate (NMDA) receptor antagonist that blocks the ion channel in a dose-dependent manner [9]. Magnesium blocks calcium channels associated with NMDA receptors, which is considered as the main mechanism through which it achieves its central effects $[10,11]$. Alternatively, there is evidence suggesting that its antinociceptive mechanism can arise through blockade of other ion channels and modulation of neurotransmitter release [12-16].

Literature data indicate that magnesium and ketamine can interact in additive, antagonistic and supraadditive manners [17-23]. Previously we demonstrated that ketamine and magnesium individually had no effects on the tail immersion test in rats, but in combination they can interact synergically [24]. The aim of the present study was to investigate the role of serotonergic, noradrenergic and GABAergic systems in ketamine-magnesium sulfate-induced analgesia. 


\section{MATERIALS AND METHODS}

\section{Ethical approval}

The experimental animals were handled as prescribed by the Ethics Committee for Animal Research and Welfare of the Faculty of Medicine, University of Belgrade (Permit $N^{\circ}$ 3416/2). All experiments were approved by the Ethical Council for the Protection of Experimental Animals of the Ministry of Agriculture, Forestry and Water Management of the Republic of Serbia, which operates in accordance with the Animal Welfare Law of the Republic of Serbia and the International Association for the Study of Pain (IASP) Guidelines for the Use of Animals in Research.

\section{Animals}

The study was performed using 120 male Wistar rats (Military Farm, Belgrade, Serbia) weighing 200-250 g. The animals were housed in groups of three in Plexiglass cages $(42.5 \times 27 \times 19 \mathrm{~cm})$ under standard conditions of temperature $\left(22 \pm 1^{\circ} \mathrm{C}\right)$, relative humidity $(60 \%)$ and a $12 \mathrm{~h}$ light/dark cycle, with lights on at 08:00. Food and water were freely available, except during the experimental procedures. The animals were fed standard rat pellets obtained from the Veterinary Institute Subotica, Serbia. The experiments were conducted by the same experimenter on consecutive days, always at the same time of the day, between 08:00 and 14:00, to avoid diurnal variation in the behavioral tests. The animals were unrestrained throughout, except during testing. Each animal was used only once and was killed at the end of the experiments by an intraperitoneal (ip) injection of sodium thiopental (200 mg/kg).

\section{Administration of drugs}

Ketamine (InresaArzneimittel GmbH, Freiburg, Germany) and magnesium sulfate (Zorka, Šabac, Serbia) were dissolved in $0.9 \% \mathrm{NaCl}$ and injected intraperitoneally (ip) and subcutaneously (sc) respectively, in a final volume of $2 \mathrm{ml} / \mathrm{kg}$. Magnesium sulfate was administered $5 \mathrm{~min}$ after ketamine injection. Antagonists (methysergide maleate, yohimbine hydrochloride and bicuculline (Sigma-Aldrich Chemical Co., St Louis, Mo., $\mathrm{SAD}$ ), were administered sc $5 \mathrm{~min}$ before ketamine [24]. To test whether the $0.9 \%$ $\mathrm{NaCl}$ injection had any effect on the antinociception, the same volume of $0.9 \% \mathrm{NaCl}$ was administered to a control group of rats.

\section{Tail-immersion test}

In the first set of experiments, the analgesic activity was determined using a tailimmersion test. The rat was placed in a hemicylindrical Plexiglass cage with its tail hanging freely outside the cage. The distal $5 \mathrm{~cm}$ of the tail was immersed in a warm water bath $\left(55 \pm 0.5^{\circ} \mathrm{C}\right)$, and the time for tail-withdrawal was measured to the nearest $0.1 \mathrm{~s}$. Animals that had a tail-withdrawal response within 1-2 s were selected for the study. To minimize tissue damage by repeated testing, a cut-off time of $10 \mathrm{~s}$ was 
adopted. The pre-medication latency was determined from an average of two premedication determinations obtained with a $30 \mathrm{~min}$ interval. There was no difference in basal tail-withdrawal latency between the tested groups $(\mathrm{p}>0.05)$. Post-medication latency was measured after the ip and/or sc administrations of the test compounds (or $0.9 \% \mathrm{NaCl}$ in the control group) at 30, 60, 90, 120, 150 and $180 \mathrm{~min}$.

\section{Statistical Analysis}

The differences between the corresponding means in tail-withdrawal latency were verified using one-way analysis of variance (ANOVA), followed by Tukey's HSD post hoc test [25]. A p $<0.05$ was considered to be statistically significant.

\section{RESULTS AND DISCUSSION}

Previously we showed by the (rat) tail-immersion test that ketamine at a dose of $5 \mathrm{mg} /$ $\mathrm{kg}$ and magnesium sulfate at a dose of $5 \mathrm{mg} / \mathrm{kg}$ did not produce an antinociceptive effect, however, ketamine $(5 \mathrm{mg} / \mathrm{kg})$ in combination with magnesium sulfate $(5 \mathrm{mg} /$ $\mathrm{kg}$ ) had an antinociceptive effect $[24,26]$. The mechanism of the antinocicetive effect of this combination remained unknown. The present study explores the influence of serotonergic, noradrenergic and GABAergic systems in the antinociceptive effect of the ketamine-magnesium sulfate combination.

Serotonin has a complex role (it can inhibit and facilitate) in the process of transmission and perception of pain impulses. Different 5-HT receptors are distributed throughout the central and peripheral nervous systems and mediate these effects [27]. Electrophysiological studies have shown that 5-HT1 receptors are mainly responsible for antinociception, and that the activation of 5-HT2 receptors underlies pronociceptive effects [28,29].

In the present study, at doses of 0.5 and $1 \mathrm{mg} / \mathrm{kg}$, methysergide antagonized the antinociceptive effect of ketamine-magnesium sulfate combination $(\mathrm{p}<0.05)$ (Figure 1A). The effect of both doses was significant at 60 min after ketamine administration. There was no statistical significance between the effects produced by different doses of methysergide when used in combination with the ketamine-magnesium sulfate combination ( $\mathrm{p}>0.05$ ) (Figure 1A). Methysergide $(0.5$ and $1 \mathrm{mg} / \mathrm{kg}, \mathrm{sc}$ ) administered alone did not have an antinociceptive effect in comparison to $0.9 \% \mathrm{NaCl}(\mathrm{p}>0.05)$ (Figure 1B).

The finding that methysergide as a non-selective antagonist of 5-HT receptors antagonized the antinociceptive effects of the ketamine-magnesium sulfate combination suggests that serotonergic receptors are involved directly or indirectly in the antinociceptive effect of this combination. It has been previously shown that (S)ketamine can act as an antagonist of 5-HT(3) receptors [30]. Since neither ketamine, nor magnesium possesses direct agonist activity at 5-HT receptors and literature data indicate that ketamine augments endogenous anti-nociceptive and antidepressant 
systems via its serotonergic activation and inhibition of re-uptake [31-33], it would seem that the descending serotonergic inhibitory pathway is implicated in the mechanism of the action of ketamine-magnesium sulfate combination. In addition, magnesium is well known for its NMDA receptor ion channel blocking effect, modulatory action on different ion channels and neurotransmitters release [12-16]. Moreover, the finding that ketamine interacts synergically with magnesium sulfate suggests the activation of different and complementary mechanisms, since the activation only of common mechanism would presumably produce an additive interaction [34].
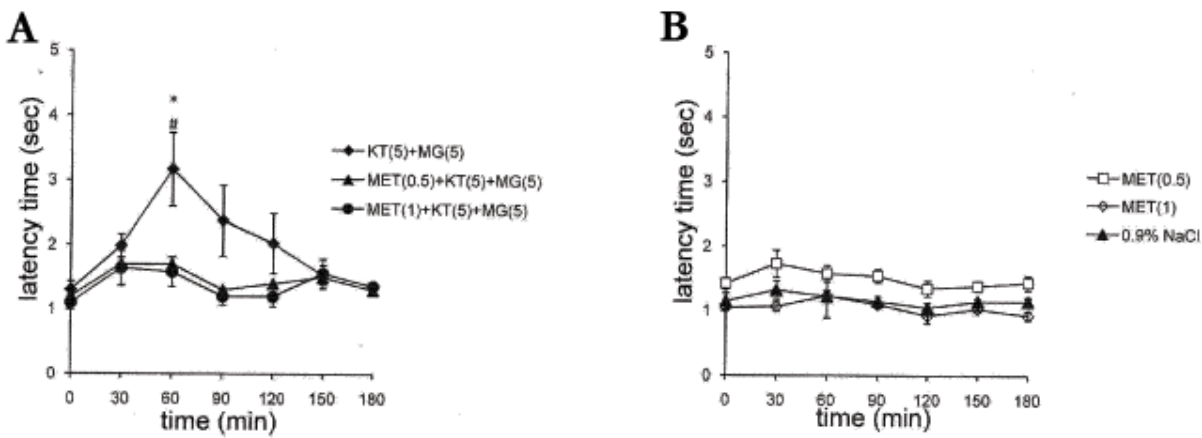

Figure 1. Antinociceptive effects of: A) combination of ketamine (KT, $5 \mathrm{mg} / \mathrm{kg}$, ip), magnesium sulfate $(5 \mathrm{mg} / \mathrm{kg}$ ) and methysergide (MET, 0.5 and $1 \mathrm{mg} / \mathrm{kg}$, sc) and B) methysergide (MET, 0.5 and $1 \mathrm{mg} / \mathrm{kg}, \mathrm{sc})$. Each point is the mean \pm SEM of the antinociceptive latency time in seconds (s) obtained in 6-8 rats. The latency time is the reaction time (in s) of a rat tail exposed to hot water. Statistical significance exists between KT(5)-MG(5) and MET(0.5)-KT(5)-MG(5) $\left({ }^{*} \mathrm{p}<0.05\right) ; \mathrm{KT}(5)-\mathrm{MG}(5)$ and MET(1)-KT(5)-MG(5) (\#p<0.05) (One-Way ANOVA, Tukey's HSD test).

GABA modulates spinal and supraspinal levels of analgesia as well as peripheral pain signaling [35,36]. Endogenous peripheral GABA could arise from primary afferent fibers and act at $\mathrm{GABA}_{\mathrm{A}}$ receptors present on some unmyelinated afferent axons [35]. Both directly and indirectly acting GABA-mimetic agents, including antiepileptic drugs, produce analgesia in a variety of animal test systems.

In the present study, bicucculine $(0.5$ and $1 \mathrm{mg} / \mathrm{kg}, \mathrm{sc})$ administered alone had no influence on antinociception in rats $(\mathrm{p}>0.05)$ (Figure 2B). At doses of $0.5 \mathrm{mg} / \mathrm{kg}$ and 1 $\mathrm{mg} / \mathrm{kg}$ bicucculine antagonized the antinociceptive effect of the ketamine-magnesium sulfate combination $(\mathrm{p}<0.05)$ (Figure $2 \mathrm{~A})$. The effect of bicuccline appeared at $30 \mathrm{~min}$ and lasted 90 min $(\mathrm{p}<0.05)$ (Figure 2A). The maximum effect was achieved at the 60 min time point. There was no statistical difference between the effects of the different doses of bicucculine (1 and $2 \mathrm{mg} / \mathrm{kg}$ ) and the ketamine ( $5 \mathrm{mg} / \mathrm{kg}$ )-magnesium sulfate combination ( $5 \mathrm{mg} / \mathrm{kg})(\mathrm{p}>0.05)$ (Figure 2A).

Our experiments revealed that, bicuculline, a selective, competitive antagonist of $\mathrm{GABA}_{\mathrm{A}}$ receptors, inhibited the systemic antinociceptive effect of the ketamine- 
magnesium sulfate combination. This data indicates that $\mathrm{GABA}_{\mathrm{A}}$ receptors, at least in part, are involved in the antinociceptive effect of the ketamine-magnesium sulfate combination. This interaction can be interpreted as that ketamine or magnesium sulfate interact with $\mathrm{GABA}_{\mathrm{A}}$ receptors either directly or indirectly, thereby potentiating GABAergic inhibitory neurotransmission. In agreement with this, some preclinical data and one human single-photon emission computerized tomography (SPECT) study suggested that ketamine modulates $\mathrm{GABA}_{\mathrm{A}}$ activity $[37,38]$.
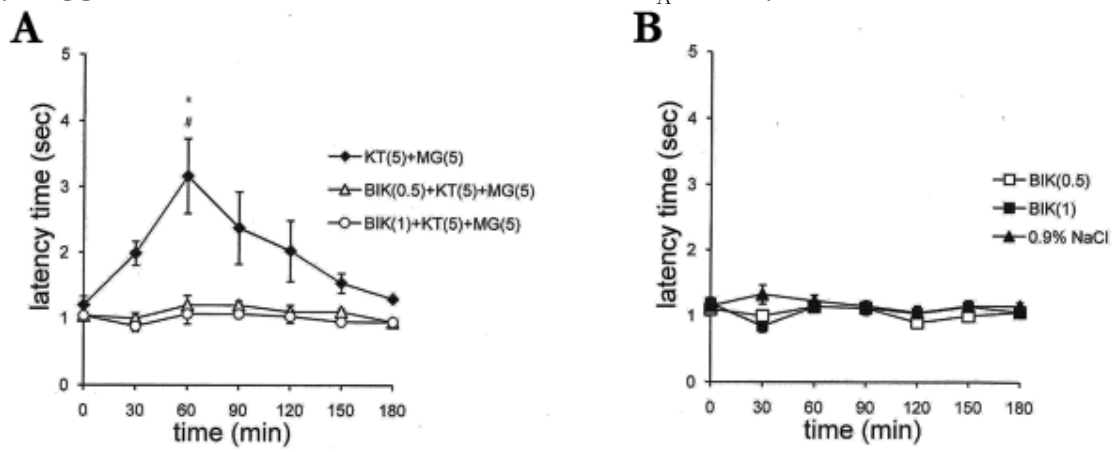

Figure 2. Antinociceptive effects of A) combination of ketamine (KT, $5 \mathrm{mg} / \mathrm{kg}$, ip), magnesium sulfate $(5 \mathrm{mg} / \mathrm{kg}$ ) and bicucculine (BIK, 0.5 and $1 \mathrm{mg} / \mathrm{kg}$, sc), and B) bicucculine (BIK, 0.5 and $1 \mathrm{mg} / \mathrm{kg}, \mathrm{sc}$ ). Each point is the mean \pm SEM of the antinociceptive latency time in seconds (s) obtained in 6-8 rats. The latency time is the reaction time (in s) of a rat tail exposed to hot water. Statistical significance exists between $\mathrm{KT}(5)-\mathrm{MG}(5)$ and $\mathrm{BIK}(0.5)-\mathrm{KT}(5)-\mathrm{MG}(5)$ $\left({ }^{*} \mathrm{p}<0.05\right) ; \mathrm{KT}(5)-\mathrm{MG}(5)$ and $\mathrm{BIK}(1)-\mathrm{KT}(5)-\mathrm{MG}(5)(\# \mathrm{p}<0.05)$ (One-Way ANOVA, Tukey's HSD test).

Our data also indicate that $\alpha_{2}$-adrenergic receptors are involved in the antinociceptive effect of the ketamine-magnesium sulfate combination. At a dose of $0.5 \mathrm{mg} / \mathrm{kg}$, yohimbine did not affect the antinociceptive effect of the ketamine-magnesium sulfate combination, however, at doses of 1 and $3 \mathrm{mg} / \mathrm{kg}$, yohimbine abolished the effect of this combination (Figure 3A). The maximum effect was achieved at the $60 \mathrm{~min}$ time point. Yohimbine $(0.5,1$ and $3 \mathrm{mg} / \mathrm{kg})$ did not produce anantinociceptive effect in rats $(\mathrm{p}>0.05)$ (Figure 3B).

The ketamine-magnesium sulfate combination could interact directly (binding to receptors) and/or indirectly (potentiation of noradrenergic neurotransmission) with receptors. It has been established that the noradrenergic system is often involved in the analgesic effect of different substances [39,40]. Activation of $\alpha_{2}$-adrenergic receptors has been shown to inhibit nociceptive transmission at the level of the spinal cord through presynaptic activity, inhibiting the release of excitatory neurotransmitters from primary afferent terminals, as well as through postsynaptic sites [41]. Recordings performed on spinal cord slices revealed that activation of $\alpha_{2}$-adrenergic receptors hyperpolarized neurons and was thus inhibitory. There is no data about the binding of ketamine or magnesium sulfate to $\alpha_{2}$-adrenergic receptors nor about the possible impact of this combination on endogenous norepinephrine levels. However, it has been previously reported that ketamine activates the descending noradrenergic 
pathway [7,31]. It was shown that ketamine increased NA release from the medial prefrontal cortex [42].
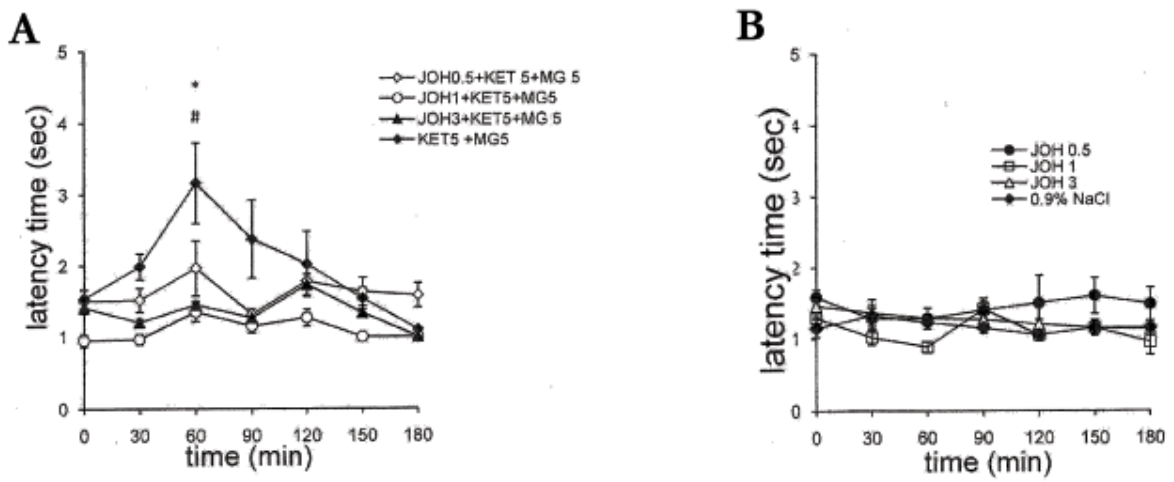

Figure 3. Antinociceptive effects of A) combination of ketamine ( $\mathrm{KT}, 5 \mathrm{mg} / \mathrm{kg}$, ip), magnesium sulfate $(5 \mathrm{mg} / \mathrm{kg}$ ) and yohimbine $(\mathrm{JOH}, 0.5,1$ and $3 \mathrm{mg} / \mathrm{kg}$, sc), and B) yohimbine (JOH, $0.5,1$ and $3 \mathrm{mg} / \mathrm{kg}$, sc). Each point is the mean \pm SEM of the antinociceptive latency time in seconds (s) obtained in 6-8 rats. The latency time is the reaction time (in s) of a rat tail exposed to hot water. Statistical significance exists between KT(5)-MG(5) and JOH(1)-KT(5)$\mathrm{MG}(5)\left({ }^{*} \mathrm{p}<0.05\right) ; \mathrm{KT}(5)-\mathrm{MG}(5)$ and $\mathrm{JOH}(3)-\mathrm{KT}(5)-\mathrm{MG}(5)(\# \mathrm{p}<0.01)$ (One-Way ANOVA, Tukey's HSD test).

\section{CONCLUSION}

The results of the present study suggest that serotonergic, noradrenergic and GABAergic systems are involved, at least in part, in the antinociceptive effect of the ketamine-magnesium sulfate combination in acute pain in rats.

\section{Acknowledgment}

This work was supported by the Ministry of Education, Science and Technological Development of the Republic of Serbia (Grant No. 175023).

\section{Authors' contributions}

KSV and SV conceived and designed the experiments; KSV performed the experiments; KSV, SV, RS and ND analyzed the data; KSV, BM, DS and MK contributed reagents/ materials/analysis tools. KSV, SV and MP wrote the paper.

\section{Declaration of conflicting interests}

The author(s) declared no potential conflicts of interest with respect to the research, authorship, and/or publication of this article. 


\section{REFERENCES}

1. Wei H, Petrovaara A: MK-801, an NMDA receptor antagonist, in the rostroventromedial medulla attenuates development of neuropathic symptoms in the rat. Neroreport 1999, 10:2933-7.

2. Garraway SM, Hochman S: Pharmacological characterization of serotonin receptor subtypes modulating primary afferent input to deep dorsal horn neurons in the neonatal rat. Br J Pharmacol 2001, 132(8):1789-98.

3. Roczniak W, Wróbel J, Dolczak L, Nowak P: Influence of central noradrenergic system lesion on the serotoninergic 5-HT3 receptor mediated analgesia in rats. Adv Clin Exp Med 2013, 22(5):629-38.

4. Dickenson AH, Chapman V, Green GM: The pharmacology of excitatory and inhibitory amino acid-mediated events in the transmission and modulation of pain in the spinal cord. Gen Pharmacol 1997, 28(5):633-8.

5. Vaughan CW, Ingram SL, Connor MA, Christie MJ: How opioids inhibit GABA-mediated neurotransmission. Nature 1997, 390(6660):611-4.

6. Persson J: Wherefore ketamine? Current Opinion in Anaesthesiology 2010, 23:455- 60.

7. Sleigh J, Harvey M, Voss L, Denny B: Ketamine-more mechanisms of action than just NMDA blockade. Trends Anaesth Crit Care 2014, 4:76-81.

8. Hirota K, Lambert DG. Ketamine: Ketamine: new uses for an old drug? British Journal of Anaesthesia 2011; 107:123-6.

9. $\mathrm{Na}$ HS, Ryu JH, Do SH: The role of magnesium in pain. In: Magnesium in the central nervous system. Adelaide, South Australia: University of Adelaide Press; 2011, 157-165.

10. Siwek M, Wróbel A, Dudek D, Nowak G, Zieba A: The role of copper and magnesium in the pathogenesis and treatment of affective disorders. Psychiatr Pol 2005, 39(5):911-20.

11. Decollogne S, Tomas A, Lecerf C, Adamowicz E, Seman M: NMDA receptor complex blockade by oral administration of magnesium: comparison with MK-801. Pharmacol Biochem Behav 1997, 58(1):261-8.

12. Mak DO, Foskett JK: Effects of divalent cations on single-channel conduction properties of Xenopus IP3 receptor. Am J Physiol 1998, 275(1 Pt 1): C179-C188.

13. Shi J, Cui J: Intracellular $\mathrm{Mg}(2+)$ enhances the function of BK-type $\mathrm{Ca}(2+)$-activated $\mathrm{K}(+)$ channels. J Gen Physiol 2001, 118:589-606.

14. Shi J, Krishnamoorthy G, Yang Y, Hu L, Chaturvedi N, Harilal D, Qin J, Cui J: Mechanism of magnesium activation of calcium-activated potassium channels. Nature 2002, 418:876880.

15. Shimosawa T, Takano K, Ando K, Fujita T: Magnesium inhibits norepinephrine release by blocking $\mathrm{N}$-type calcium channels at peripheral sympathetic nerve endings. Hypertension 2004, 44:897-902.

16. Guiet-Bara A, Durlach J, Bara M: Magnesium ions and ionic channels: activation, inhibition or block - a hypothesis. Magnes Res 2007, 20:100-106.

17. Harrison NL, Simmonds MA: Quantitative studies on some antagonists of Nmethyl-daspartate in slices of rat cerebral cortex. Br J Pharmacol 1985, 84:381-91.

18. MacDonald fF, Bartlett MC, Mody I, Pahapill P, Reynolds JN, Salter MW, Schneiderman JH, Pennefather PS: Action of ketamine, phencyclidine and MK-801 on NMDA receptor currents in cultured mouse hippocampal neurones. The Journal of Physiology 1991, 432: 483-508. 
19. Irifune M, Shimizu T, Nomoto M, Fukuda T: Ketamine-induced anesthesia involves the N-methyl-d-aspartate receptor-channel complex in mice. Brain Res. 1992, 596:1-9.

20. Liu HT, Hollmann MW, Liu WH, Hoenemann CW, Durieux ME: Modulation of NMDA receptor function by ketamine and magnesium: Part I. AnesthAnalg 2001, 92:1173-81.

21. Orser B, Smith D, Henderson S, Gelb A: Magnesium deficiency increases ketamine sensitivity in rats. Canadian Journal of Anesthesia 1997, 44:883-90.

22. Queiroz-Castro P, Egger C, Redua MA, Rohrbach BW, Cox S, Doherty T: Effects of ketamine and magnesium on the minimum alveolar concentration of isoflurane in goats. Am J Vet Res 2006, 67:1962-6.

23. DeRossi R, Pompermeyer CT, Silva-Neto AB, Barros AL, Jardim PH, Frazílio FO: Lumbosacral epidural magnesium prolongs ketamine analgesia in conscious sheep. Acta Cirurgica Brasileira 2012, 27:137-43.

24. Savić Vujović K, Vučković S, Srebro D, Medić B, Stojanović R, Vučetić Č, Prostran M: A synergistic interaction between magnesium sulfate and ketamine on the inhibition of acute nociception in rats. Eur Rev Med Pharmacol Sci 2015, 19 (13):2503-2509.

25. Milovanović M, Vučković S, Prostran M, Trailović S, Jovanović M: L-arginine-no system participates in the analgesic effect of flunixin meglumine in the rat. Acta VeterinariaBeograd 2016, 66 (1):103-114.

26. Vučković SM, Savić Vujović KR, Srebro DP, Medić BM, Stojanović RM, Vučetić CS, Divac N, Prostran MS: The antinociceptive efficacy of morphine-ketamine-magnesium combination is influenced by the order of medication administration. Eur Rev Med Pharmacol Sci 2015, 19(17): 3286-94.

27. Kayser V, Bourgoin S, Viguier F, Michot B, Michel Hamon M: Toward Deciphering the Respective Roles of Multiple 5-HT Receptors in the Complex Serotonin-Mediated Control of Pain. In: Pharmacology of Pain. Seattle, United States: IASP Press; 2010, 185-207.

28. Millan MJ: Descending control of pain. Prog Neurobiol 2002, 66:355-474.

29. Lopez-Garsia JA: Serotonergic modulation of spinal sensory circuits. Curr Top Med Chem 2006, 6:1987-1996.

30. Rammes G, Rupprecht R, Ferrari U, Zieglgänsberger W, Parsons CG: The N-methylD-aspartate receptor channel blockers memantine, MRZ 2/579 and other amino-alkylcyclohexanesantagonise 5-HT(3) receptor currents in cultured HEK-293 and N1E-115 cell systems in a non-competitive manner. Neurosci Lett 2001, 306(1-2):81-4.

31. Koizuka S, Obata H, Sasaki M, Saito S, Goto F: Systemic ketamine inhibits hypersensitivity after surgery via descending inhibitory pathways in rats. Can J Anaesth 2005, 52(5):498e505.

32. duJardin KG, Müller HK, Elfving B, Dale E, Wegener G, Sanchez C: Potential involvement of serotonergic signaling in ketamine's antidepressant actions: A critical review. Prog Neuropsychopharmacol Biol Psychiatry 2016, 71:27-38.

33. Pham TH, Mendez-David I, Defaix C, Guiard BP, Tritschler L, David DJ, Gardier AM: Ketamine treatment involves medial prefrontal cortex serotonin to induce a rapid antidepressant-like activity in BALB/cJ mice. Neuropharmacology. 2017, 112(Pt A):198209.

34. Savić Vujović K, Vučković S, Vasović D, Medić B, Knežević N, Prostran M: Additive and antagonistic antinociceptive interactions between magnesium sulfate and ketamine in the rat formalin test. Acta Neurobiol Exp 2017, 77:132-142.

35. Sawynok J: Topical and peripherally acting analgesics. Pharmacol Rev 2003, 55:1-20. 
36. Sawynok J: GABAergic mechanisms of analgesia: an update. Pharmacol Biochem Behav 1987, 26(2):463-74.

37. Heinzel A, Steinke R, Poeppel TD, Grosser O, Bogerts B, Otto H, Northoff G: S-ketamine and GABA-A-receptor interaction in humans: an exploratory study with I-123-iomazenil SPECT. Hum Psychopharmacol 2008, 23(7):549-54.

38. Lin LH, Chen LL, Zirrolli JA, Harris RA: General anesthetics potentiate gammaaminobutyric acid actions on gamma-aminobutyric acid. A receptors expressed by Xenopus oocytes: lack of involvement of intracellular calcium. J Pharmacol Exp Ther 1992, 263(2):569-78.

39. Vucković SM, Tomić MA, Stepanović-Petrović RM, Ugresić N, Prostran MS, Bosković B: The effects of alpha2-adrenoceptor agents on anti-hyperalgesic effects of carbamazepine and oxcarbazepine in a rat model of inflammatory pain. Pain 2006, 125(1-2):10-9.

40. Stoetzer C, Leffler A, Filitz J: Perioperative management of patients with opioid tolerance and misuse. Anasthesiol Intensiv med Notfallmed Schmerzther 2015, 50(2):102-11.

41. Michael H. Ossipov, Gregory O. Dussor, Frank Porreca: Central modulation of pain. J Clin Invest 2010, 120(11): 3779-3787.

42. Kubota T, Anzawa N, Hirota K, Yoshida H, Kushikata T, Matsuki A: Effects of ketamine and pentobarbital on noradrenaline release from the medial prefrontal cortex in rats. Can J Anaesth 1999, 46(4):388-92.

\title{
UTICAJ SEROTONERGIČKOG, NORADRENERGIČKOG I GABERGIČKOG SISTEMA U ANTINOCICEPTIVNOM EFEKTU KOMBINACIJE KETAMIN-MAGNEZIJUM SULFATA U AKUTNOM BOLU
}

\author{
SAVIĆ VUJOVIĆ Katarina, VUČKOVIĆ Sonja, STOJANOVIĆ Radan, \\ DIVAC Nevena, MEDIĆ Branislava, SREBRO Dragana, KADIJA Marko, \\ PROSTRAN Milica
}

Ketamin i magnezijum mogu stupiti u aditivnu, supraaditivnu i antagonističku interakciju u analgeziji i anesteziji. Ketamin je nekompetitivni NMDA antagonist. Magnezijum je endogeni nekompetitivni NMDA antagonist koji blokira jonski kanal na voltažno zavistan način. U testu potapanja repa u toplu vodu, dokazano je da ketamin i magnezijum stupaju u sinergističku interakciju.

Cilj rada: utvrditi da li serotonergički, GABA-ergički i noradrenergički sistem učestvuju $\mathrm{u}$ analgetičkom efektu ketamin-magnezijum sulfat kombinacije.

Eksperimenti su izvođeni na mužjacima pacova Wistar soja (200-250 g). Antinocicepcija je merena pomoću testa potapanja repa u toplu vodu.

Metizergid (0.5 i $1 \mathrm{mg} / \mathrm{kg}$, sc), primenjen sam, nije uticao na nocicepciju kod pacova. Metizergid (0.5 i $1 \mathrm{mg} / \mathrm{kg}$, sc) je antagonizovao antinociceptivni efekt ketamin (5 mg/ 
$\mathrm{kg})$-magnezijum sulfat (5mg/kg) kombinacije. Bikukulin (0.5 i $1 \mathrm{mg} / \mathrm{kg}$, sc) primenjen sam nije imao efekt $u$ testu potapanja repa u toplu vodu, a antagonizovao je antinociceptivni efekt ketamin ( $5 \mathrm{mg} / \mathrm{kg}$ )-magnezijum sulfat ( $5 \mathrm{mg} / \mathrm{kg}$ ) kombinacije. Johimbin $(0.5,1 \mathrm{i} 3 \mathrm{mg} / \mathrm{kg}$, sc) nije uticao na nocicepciju kod pacova kada je primenjen samostalno. U dozi od $0.5 \mathrm{mg} / \mathrm{kg}$, johimbin nije uticao na kombinaciju ketamin (5 mg/ $\mathrm{kg}$ )-magnezijum sulfat ( $5 \mathrm{mg} / \mathrm{kg}$ ), dok je u dozama od of 1 i $3 \mathrm{mg} / \mathrm{kg}$ antagonizovao antinociceptivne efekte ove kombinacije.

Serotonergički, noradrenergičkii GABA-ergički sistem učestvuju bar delimično u antinocicptivnom efektu ketamin-magnezijum sulfat kombinacije kod pacova. 